\title{
Phytochemical screening and antidiabetic effect of extracts of the seeds of Citrullus lanatus in alloxan-induced diabetic albino mice
}

\author{
Umar Muhd Sani \\ Chemistry Department, Nigeria Police Academy, Wudil, Kano State, Nigeria.
}

\begin{tabular}{l} 
ARTICLE INFO \\
\hline Article history: \\
Received on: 07/09/2014 \\
Revised on: 23/10/2014 \\
Accepted on: 14/12/2014 \\
Available online: 28/03/2015 \\
\hline Key words: \\
Alloxan monohydrate, \\
Citrullus lanatus, diabetes \\
mellitus, physiological saline, \\
glibenclamide, albino mice.
\end{tabular}

\begin{abstract}
Diabetes mellitus is a major and current epidemic disease of the human race implicated with numerous clinical manifestations. A number of protein-rich seeds such as that of Citrullus lanatus (watermelon) are commonly used in traditional medicine with increasing acclaimed efficacy against diabetes mellitus. In this study the effects of petroleum ether and ethanol extracts of the seeds of Citrullus lanatus on blood glucose levels in alloxan-induced diabetes in mice have been investigated. Hyperglycemia was induced by the injection of $150 \mathrm{mg} / \mathrm{kg}$ (i.p.) of alloxan monohydrate freshly dissolved in physiological saline. Doses $(150,200$ and $250 \mathrm{mg} / \mathrm{kg}$ ) per os, of the extracts were separately administered to a group of five diabetic mice in the study. The activity was compared with reference standard glibenclamide $(2 \mathrm{mg} / \mathrm{kg}$, p.o.) and negative control of physiological saline. Treatment of alloxan-induced diabetic mice with the crude extracts of $C$. lanatus seeds brought down the raised blood glucose levels significantly $(P<0.05)$ in a dose-dependent manner. The ethanol extract was found to have more antidiabetic effect than the petroleum ether extract. Phytochemical screening of the seed extracts of Citrullus lanatus indicated the presence of steroids, alkaloids, flavonoids, terpenoids, and saponins in both the ethanol and petroleum ether extracts. In addition, anthraquinones, tannins and reducing sugar were detected in the ethanol extract.
\end{abstract}

\section{INTRODUCTION}

The current epidemic of diabetes mellitus (DM) in Africa, coupled with impinging poverty, clearly indicates the urgent need to develop new therapeutic drugs of cheaper and more available to face this growing health challenge. A number of plants products among which the protein-rich seeds including Citrullus lanatus, Telfairia occidentalis, Lagenaria siceraria, Cucumeropsis mannii and Cucurbita moschata are commonly used in traditional medicine with increasing acclaimed efficacy against DM (Teugwa et al., 2013). Diabetes mellitus is a major illness of the human race implicated with numerous clinical manifestations. It is a clinical syndrome characterized by chronic hyperglycemia (defects in insulin secretion, insulin action or both) resulting in aberration in carbohydrate, fat and protein metabolism. It has been reported that the chronic hyperglycemia of diabetes is associated with complications like renal failure, coronary artery disorder, neurological complications, cerebro-

* Corresponding Author

E-mail: usindabawa@yahoo.com vascular disease, blindness, and limb amputation, long term dysfunctions and failure of various organs and eventually premature death (Lyra et al., 2006)). According to the World Health Organization (WHO) projections, the diabetes population is likely to increase to 300 million or more by the year 2025 (Tielmans et al., 2007). The high cost of conventional drugs and their unavailability in many rural areas, coupled with their high incidence of side effects, posed a dare need for a change of the affair in case of modern medicine. Thus, the management of diabetes without any side effect is still a major challenge. According to the WHO, approximately $80 \%$ of the world's population currently uses herbal medicines in healing different ailments (Latha et al., 2010). However, among the estimated 400,000 plant species, only $6 \%$ have been studied for biological activity, and about $15 \%$ have been investigated phytochemically (Cragg et al., 1997; Srinivasan, 2005). This shows a need for planned activity guided phyto-pharmacological evaluation of herbal drugs. The aim of this study was to phytochemically analyse and evaluate the antidiabetic activity of the seeds of Citrullus lanatus (Kankana in Hausa). 


\section{MATERIALS AND METHODS}

\section{Plant material}

Seeds of Citrullus lanatus were collected from Unguwar Rimi market, Kaduna north, Kaduna. The seeds were bench dried for eleven days and pulverized into coarse powder and kept in polythene bags at room temperature, ready for extraction.

\section{Extraction of plant material}

The dried pulverized seed $(300 \mathrm{~g})$ was macerated with $1000 \mathrm{mls}$ of petroleum ether $\left(60-80{ }^{\circ} \mathrm{C}\right)$ for three days at room temperature and filtered and this was repeated twice. The combined filtrate was distilled using a rotary evaporator and then air-dried to obtain the petroleum ether extract. This procedure was repeated using ethanol on the residue of the seeds and after filtration the combined filtrate was then distilled to afford the ethanol extracts.

\section{Phytochemical screening}

Phytochemical screening was carried out on the two extracts (petroleum ether and ethanol) of Citrullus lanatus peel using standard procedures and tests (Trease and Evans, 1989; Sofowora, 1993) to determine the presence of alkaloids, tannins, terpenoids, flavonoids, reducing sugar, anthraquinones, and saponins.

\section{Pharmacological study \\ Animals}

White albino mice (22-32g) of both sexes obtained from biochemistry department Kaduna state University, Kaduna were used for the experiment. The animals were kept under standard environmental conditions of temperature, relative humidity, and fed with standardized pellets and water ad libitum during the period in aluminum cages. The mice were fasted for $12 \mathrm{hrs}$ before experimentation but were allowed free access to water.

\section{Experimental design}

Hyperglycemia was induced by intraperitoneal injection of $150 \mathrm{mg} / \mathrm{kg}$ body weight alloxan monohydrate, freshly dissolved in regular saline $0.9 \%$ physiological saline immediately before use, to overnight fasted albino mice. After 7 days, animals with fasting blood glucose level $\geq 126 \mathrm{mg} / \mathrm{dl}$ ( $\geq 7.0 \mathrm{mmol} / \mathrm{dl}$ ) (Vijan, 2010) or more were considered diabetic and employed in the study. The mice were then grouped into 5 groups of five mice each as follows:

Group 1: Served as positive control and received glibenclamide (2 $\mathrm{ml} / \mathrm{kg}$ body weight)

Group 2: Served as negative control receiving physiological saline $(10 \mathrm{ml} / \mathrm{kg})$

Group 3: Received petroleum ether extract at $150 \mathrm{mg} / \mathrm{kg}$ body weight

Group 4: Received petroleum ether extract at $200 \mathrm{mg} / \mathrm{kg}$

Group 5: Received petroleum ether extract at $250 \mathrm{mg} / \mathrm{kg}$

Group 6: Received ethanol extract at $150 \mathrm{mg} / \mathrm{kg}$ body weight
Group 7: Received ethanol extract at $200 \mathrm{mg} / \mathrm{kg}$

Group 8: Received ethanol extract at $250 \mathrm{mg} / \mathrm{kg}$

The animals were treated once with each dose and fasting blood glucose concentrations were measured at $0,1,3,6$ and 12 hours. Blood samples were taken by a snip-cut at the tip of the tail and blood sugar level was measured with a glucometer (a ONE TOUCH Ultra easy blood glucose monitoring system, LifeScan Europe Division of Cilag $\mathrm{GmbH}$ international $6300 \mathrm{Zug}$ Switzerland).

\section{Statistical Analysis}

All the values of fasting blood glucose were expressed as mean \pm SEM $(n=5)$ and statistical significances between the treated and control groups (glibenclamide and physiological saline) were analyzed by means of Student's t-test; $P$ values $<0.05$ were considered significant.

\section{RESULTS AND DISCUSSION}

\section{Phytochemical screening}

Table 1.0 gave the results of phytochemical studies on both the petroleum ether and ethanol extracts of the seeds of Citrullus lanatus.

Table 1: Phytochemical tests on petroleum ether and ethanol extracts of the seeds of Citrullus lanatus.

\begin{tabular}{ccc}
\hline Phytochemical & Petroleum ether extract & Ethanol extract \\
\hline Steroids & + & + \\
Alkaloids & + & + \\
Terpenoids & + & + \\
Anthraquinones & - & + \\
Flavonoids & + & + \\
Reducing sugar & - & + \\
Saponins & + & + \\
Tannins & - & + \\
\hline
\end{tabular}

Key: + = Present; - = Absent

\section{Pharmacological study}

The effects of the petroleum ether and ethanol extracts on fasting blood glucose levels in alloxan monohydrate-induced mice have been given in table 2.0 below.

Table 2: Effects of petroleum ether and ethanol extracts of the seeds of Citrullus lanatus on blood glucose levels in alloxan induced diabetic mice $(\mathrm{mg} / \mathrm{dl})$.

\begin{tabular}{|c|c|c|c|c|c|}
\hline \multirow{3}{*}{$\begin{array}{c}\begin{array}{c}\text { Test } \\
\text { material }\end{array} \\
\text { Controls }\end{array}$} & \multicolumn{5}{|c|}{ Blood glucose levels in mg/dl } \\
\hline & \multicolumn{5}{|c|}{ Sampling time in hours } \\
\hline & $\mathbf{0}$ & 1 & 3 & 6 & 12 \\
\hline Glibenclamide & $220 \pm 1.8$ & $121 \pm 4.3$ & $108 \pm 2.6$ & $48 \pm 2.3$ & $180 \pm 2.5$ \\
\hline Physiological saline & $144 \pm 2.7$ & $156 \pm 3.1$ & $162 \pm 1.5$ & $166 \pm 2.7$ & $162 \pm 3.5$ \\
\hline \multicolumn{6}{|l|}{$\begin{array}{l}\text { Petroleum } \\
\text { extract }\end{array}$} \\
\hline $150 \mathrm{mg} / \mathrm{kg}$ & $133 \pm 2.5$ & $80 \pm 2.8$ & $70 \pm 2.3$ & $46 \pm 1.4$ & $178 \pm 2.3$ \\
\hline $200 \mathrm{mg} / \mathrm{kg}$ & $113 \pm 3.8$ & $65 \pm 2.6$ & $55 \pm 2.9$ & $44 \pm 1.8$ & $157 \pm 2.8$ \\
\hline $250 \mathrm{mg} / \mathrm{kg}$ & $85 \pm 2.6$ & $64 \pm 2.1$ & $50 \pm 2.5$ & $36 \pm 1.3$ & $167 \pm 3.3$ \\
\hline \multicolumn{6}{|l|}{ Ethanol extract } \\
\hline $150 \mathrm{mg} / \mathrm{kg}$ & $122 \pm 2.8$ & $119 \pm 2.4$ & $97 \pm 1.5$ & $72 \pm 1.9$ & $55 \pm 1.0$ \\
\hline $200 \mathrm{mg} / \mathrm{kg}$ & $146 \pm 3.8$ & $120 \pm 1.8$ & $109 \pm 2.7$ & $83 \pm 2.9^{\dagger}$ & $76 \pm 2.6$ \\
\hline $250 \mathrm{mg} / \mathrm{kg}$ & $125 \pm 3.4$ & $81 \pm 3.2$ & $61 \pm 2.7$ & $39 \pm 1.6^{\dagger}$ & $21 \pm 1.8$ \\
\hline
\end{tabular}

$\mathrm{P}<0.05$ with respect to both Glibenclamide and Physiological saline; The data was analyzed using Student's t-test. All the results were expressed as mean \pm SEM 


\section{DISCUSSION}

The results of the phytochemical screening carried out on the extracts of Citrullus lanatus seeds have revealed the presence of flavonoids, saponins, terpenoids, alkaloids and steroids. Reducing sugar, anthraquinones and tannins have been detected only in the ethanol extract. These results were in agreement with that obtained by Johnson et al (2012) who reported that saponins, alkaloids, tannins, phenols, and flavonoids were present in the seed and rind of Citrullus lanatus.

Several authors have reported flavonoids, sterols, tannins, saponins, alkaloids and polyphenols as bioactive antidiabetic principles. The phytochemical screening of the leaf extracts (using petroleum ether, chloroform, alcohol and aqueous) of Pongamia pinnata revealed the presence of flavonoids, furoflavones, triterpenoids, carbohydrates, tannins, phytosterols and other polyphenolic compounds (Mukesh and Patil, 2010). Results indicated that ethanolic extract and aqueous extract showed the most significant antidiabetic activity which was probably due to the presence of several secondary metabolites and their synergistic properties. Pradeep (2013) reported that the maximum possibility of antidiabetic activity of the ethanolic extracts of Strobilanthes asperrimus leaves was the presence of tannins, flavonoids, and alkaloids. The antidiabetic effects $(\alpha-$ amylase and $\alpha$-glucosidase inhibition activities) of tannins extracted from some cereals, legumes, oil seeds, and vegetables have been studied (Catherine et al., 2011) and results have shown encouraging effects. . Flavonoids have also been reported to suppress glucose level significantly and the typical flavonoid, luteolin, has been found to be a strong inhibitor of $\alpha$-glucosidase (Kim et al., 2000). Alkaloids have also been severally reported to to have Antidiabetic activity. For example, Alkaloids isolated from Catharanthus roseus leaves have shown to induced antidiabetic and antioxidant properties in mouse $\beta$-TC6 pancreatic cell line (Soon et al., 2013). Generally alkaloids have been said to inhibit $\alpha$-glucosidase and decrease glucose transport through the intestinal epithelium (Mishra et al., 2010; Patel et al., 2012).

Saponin, an abundant secondary metabolite in the seed of Entada phaseoloides was reported (Zheng et al., 2012) to have dramatically reduced fasted blood glucose and serum insulin levels and alleviates hyperglycemia associated oxidative stress in type 2 diabetic. In another study, Alli et al., (2012) reported that saponin extract from the root of Garcinia kola (bitter cola) demonstrated remarkable antidiabetic activity even more than a standard antidiabetic drug metformin in alloxan-induced diabetic rats. Alloxan monohydrate destroys $\beta$-cells of Islets of Langerhans of the pancreas resulting in a decrease in endogenous insulin secretion and paves ways for the decreased utilization of glucose by body tissues (Yamamoto et al., 1981). It results in elevation of blood glucose level, decreased protein content, increased levels of cholesterol and triglycerides (Dhanabal et al., 2007). The diabetic animals treated with both petroleum ether and ethanol extracts in this study showed decrease in blood glucose level. The antidiabetic activity of raw Citrullus lanatus rind and flesh was studied in mice using streptozotocin to induce diabetes and results have shown that blood glucose level was significantly decreased (Jiyun et al., 2011). The results of this study, using extracts of the seeds, for the first time have shown that also the seeds have some potentiality as antidiabetic medication. The percentage increase of blood glucose in the untreated group appeared to be higher than that in the treated group. Comparison of the average values of blood glucose levels in the treated and untreated (control) groups of alloxan-induced diabetic mice suggested some favorable antidiabetic effect of $C$. lanatus. However, statistical analysis using Student's t-test revealed that there is a statistically valid difference between the treated and the control groups. Both the petroleum ether and ethanol extracts exhibited significant $(\mathrm{P}<0.05)$ anti-hyperglycemic effect at $6 \mathrm{~h}$ and $12 \mathrm{~h}$ at the doses of 200 and $250 \mathrm{mg} / \mathrm{kg}$. From the present experimental results, it can be suggested that, the both extracts exhibited dose dependent action in a similar mechanism as glibenclamide i.e., by stimulation of surviving beta cells to release more insulin (Ivorra et al., 1988).

\section{CONCLUSION}

The results of this study, using extracts of the seeds, for the first time have shown that also the seeds have some potentiality as antidiabetic medication. Both the petroleum ether and ethanol extracts of the Citrullus lanatus seeds exhibited significant $(\mathrm{P}<0.05)$ antidiabetic effect. The specific secondary metabolites responsible for the antidiabetic activity are needed to be found and further investigation by fractionation of the extracts to to determine active compounds could be done in future. This might lead to the development of new drugs. On the otherhand, this study supports the traditional use of the plant for the purposes already mentioned.

\section{REFERENCE}

Alli SYR, Adanlawo IG, Oni OS. Hypoglycaemic Effect of Saponin from the Root of Garcinia kola (bitter kola) on alloxan-induced diabetic rats. Journal of Drug Delivery \& Therapeutics, 2012; 2(6):9-12.

British Medical Association, Board of Science and Education 2004. Diabetes mellitus an update for healthcare professionals. London: BMA Publications Unit.

Catherine NK, Jasper KI, Michael O, Clare M, Han KB, Vellingiri V. Antioxidant and antidiabetic properties of condensed tannins in acetonic extract of selected raw and processed indigenous food ingredients from Kenya. Journal of Food Science, 2011; 76(4):C560-7.

Ivorra MD, Paya M, Villar A. Hypoglycemic and insulin release effects of tormentic acid: A new hypoglycemic natural product. Planta Med. 1988; 54:282-5.

Johnson JT, Iwang EU, Hemen JT, Odey MO, Efiong EE, Eteng OE. Evaluation of anti-nutrient contents of watermelon Citrullus lanatus. Ann Biol Res 2012; 3(11): 5145-5150.

Kim JS, Kwon CS, Son KH. Inhibition of alpha-glucosidase and amylase by luteolin, a flavonoid. Biosci. Biotechnol. Biochem. 2000; 64 (11):2458-61.

Lee MS, Sohn CB). Anti-diabetic properties of chrysophanol and its glucoside from rhubarb rhizome. Biol Pharm Bull., 2008; 31(11): 2154-7.

Lyra RM, Oliveira D, Lins N, Cavalcanti N. Arquivos Brasileiros de Endocrinol Metabol, 2006; 50:239-249. 
Mishra SB, Raoch CHV, Ojha SK, Vijayakumar M, Verma A. An analytical review of plants for anti diabetic activity with their phytoconstituent \& mechanism of action. International Journal Pharmaceutical Sciences and Research, 2010; 1(1):29-46.

Mukesh SS, Patill MB. Antidiabetic activity of Pongamia pinnata leaf extracts in alloxan-induced diabetic rats. Int J Ayurveda Res. 2010;1(4):199-204.

Patel DK, Kumar R, Laloo D, Hemalatha S. Natural medicines from plant source used for therapy of diabetes mellitus: An overview of its pharmacological aspects. Asian Pacific Journal of Tropical Disease, 2012; pp 239-250.

Pradeep KS. Antidiabetic and antioxidant activity of strobilanthes asperrimus in rats, Journal of Global Trends in Pharmaceutical Sciences, 2013; 4(2):1067-1072.

Sofowora A, 1993. Medicinal plants and traditional medicine in Africa, 2nd edn, Spectrum Book Ltd, Ibadan, Nigeria.

Soon HT, Chung YL, Hazrina H, Aditya A, Mohammad JP, Won FW, Shiau-Chuen C, Mohd RM, Khalijah A. Antidiabetic and Antioxidant Properties of Alkaloids from Catharanthus roseus (L.) G. Don, Molecules, 2013; 18(8):9770-9784.

Teugwa CM, Thaddée B, Bruno TT, Pascaline CM, Denis Z. Anti-hyperglycaemic globulins from selected Cucurbitaceae seeds used as antidiabetic medicinal plants in Africa. BMC Complementary and Alternative Medicine, 2013; 13:63.
Tielmans A, Laloi-Michelin M, Coupaye M, Virally M, Meas T, Guillausseau P. Traitement médicamenteux du diabète de type 2 (première partie), Presse Med, 2007; 36:269-278.

Trease GE, Evans WC. 1989. Pharmacognosy, 13th edn, Bailliere Tindall, London.

Vijan, S. "Type 2 diabetes", Annals of Internal Medicine, 2010 March; 152(5):ITC31-15.

Zheng T, Shu G, Yang Z, Mo S, Zhao Y, Mei Z. Antidiabetic effect of total saponins from Entada phaseoloides (L.) in type 2 diabetic rats, J. Ethnopharmacol, 2012; 139(3):814-21.

\section{How to cite this article:}

Umar Muhd Sani. Phytochemical Screening and Antidiabetic Effects of Extracts of the Seeds of Citrullus lanatus in Alloxaninduced Diabetic Albino Mice. J App Pharm Sci, 2015; 5 (03): 051054. 